Nigerian Journal of Environmental Sciences and Technology (NIJEST)

www.nijest.com

ISSN (Print): 2734-259X ｜ＩSSN (electronic): 2734-2603

Vol 5, No. 2 October 2021, pp 404 - 412

\title{
Effect of Confining Pressures on Dynamic Response Characteristics of Silty Soils in the Niger Delta
}

\author{
Okovido J. O.* and Kennedy C. \\ Department of Civil Engineering, University of Benin, Benin City, Edo State, Nigeria \\ Corresponding Author: *johnokovido@ uniben.edu
}

https://doi.org/10.36263/nijest.2021.02.0258

\begin{abstract}
The probability of earthquake occurrence in the Niger Delta region of Nigeria was studied in this research. The resonant column/bender element tests were used for the study. Series of analysis were carried out on compacted silt in subsoil strata obtained from various locations in Rivers, Bayelsa, Delta and Akwa Ibom States. The effects of confinement on frequency, shear modulus, shear velocity and damping ratio were studied. The tests results revealed that confinement has effects on the investigated parameters. Thus, frequency response increases with increase in confinement pressure. Also, the resonance column test at various confinements revealed changes in shear modulus, accelerometer output and damping ratio. Accordingly, there was high disparity in the tested parameters as confinement pressure was increased. Similarly, the bender element tests also showed that pressure has effect on shear wave-velocity, shear modulus and damping ratio confinement. The shear modulus and shear wave-velocity generally increased as confinement pressure was increased, while damping ratio decreases as confinement pressure was increased. The variations in Resonance Column/Bender Element test parameters showed that the silty soil in the Niger Delta region, an oil and gas rich area, is likely to experience earthquake in the future. Therefore, geological data should be collated for monitoring, especially as several geological activities take place in the region.
\end{abstract}

Keywords: Earthquake, Confinement Pressure, Seismic Properties

\subsection{Introduction}

The management and analysis of earthquake activities have been proposed as a good technique for understanding the susceptibility of earthquake event (Hudyma and Potvin, 2010). Thus, seismic responses contribute to the timing, location and magnitude of seismic hazard. So, establishing an understanding of spatial and temporal characteristics of seismicity is fundamental for the effective management of seismic risk (Hudyma and Potvin, 2010; Cho et al., 2010). Spatial and temporal characteristics of seismic hazard impact on the effectiveness of strategic and tactical methods are used to manage risk associated with different sources of seismicity (Hudyma and Potvin, 2010; Potvin, 2009).

A theoretical foundation for time-dependent seismicity within mining environment is not definitive, and is tentatively addressed in some studies. Malek and Leslie (2006) suggested that the non-linear behaviour of rock mass failure is indicative of critical phenomena and is evidence of unstable conditions. This concept is discussed in detail by Mendecki and Lynch (2004), giving a theoretical basis for system excitability as a model of self-organized criticality. It is postulated that the criticality (or state of the rock mass) can be monitored by pulse tests, otherwise described as taps (blasting) or self-taps (seismic events). Furthermore, it is suggested that seismic responses to these tests contain information concerning rock mass stability. Other studies have shown that the spatial and temporal characteristics of mining-induced seismicity following large events are comparable to characteristics of earthquake main and aftershock responses (Hills and Penney, 2008; Kgarume et al., 2010; Vallejos and McKinnon, 2010). 
One of the most important geotechnical parameters, which can be used to estimate earthquake factors, is the shear wave velocity. Shima (1978) found that the analytically calculated amplification factor is linearly related to the ratio of shear wave velocity of the surface layer to that of bedrock. When the bedrock shear wave velocity is found to be relatively constant over a wide area, the relative amplification in each locality can be obtained from the shear wave velocity of the surface layer. Various researchers (Borchedt et al., 1994; Chan and Jenu, 2014; Szilvágyi et al., 2016; Gluchowski et al., 2020) have shown the significance of shear wave velocity in the study of soil geotechnical analysis.

In the study by Balendra (2011) on the behaviour of long-distance travelling earthquake wave property, he observed that when high-frequency earthquake wave decay rapidly, the low-frequency waves have long-period waves, in which energy dissipation is very limited. This becomes amplified due to upward propagation and soft soil deposit whose frequency is very near to seismic wave frequency. Dynamic soil responses, such as frequency, shear wave velocity, shear modulus and damping ratio, have shown to be affected by soil confining pressure. Amini (1993), using transfer function estimators, showed that increase in confining pressure of Ottawa-sand also increased damping, but does not affect the shear modulus as there was no change in the frequency response. Hence, concluded that the shear modulus does not depend on confining pressure rather, on the frequency. However, the work by Asef and Najibi (2013) showed that both shear wave velocity and shear modulus increased with increase in confining pressure. These changes could result to earthquake occurrence at certain conferment, and studies have revealed that earthquake occurrence can be estimated by the values of shear wave velocity (Anbazhagan et al., 2009; UmaMaheshwari et al., 2010).

In this study, the resonant column and bender elements tests were used to study silt soil samples in selected States of the Niger Delta region of Nigeria. The soil dynamic properties studied include frequency response, shear modulus, shear, damping ratio and accelerometer output.

\subsection{Methodology}

\subsection{Description of study area}

The Niger Delta is found in the Southern Nigeria, West African, and it is situated in the Gulf of Guinea between longitude $5.35^{\circ} \mathrm{E}$ to $8.45^{\circ} \mathrm{E}$ and latitude $4.5^{\circ} \mathrm{N}$ to $5.65^{\circ} \mathrm{N}$ and covers a distance of about $36,260 \mathrm{~km}^{2}$. The region has the largest wetland in Africa and third in the world consisting of flat low lying swampy terrain that is criss-crossed by meandering and anatomising streams, rivers and creeks (Emoyan et al., 2008). The Niger Delta region constitutes 9 Sates out of the 36 States in Nigeria, which include Abia Akwa Ibom, Bayelsa, Cross River, Delta, Edo, Imo, Ondo and Rivers States, with its headquarters in Port Harcourt, the Capital of Rivers State. The region contributes immensely to the economic growth and development of the Nigeria, particularly for crude oil and gas production. The area lies lithostratigraphically within the traditional Benin, Agbada and Akata Formations. Sediments in the Benin Formation represent the subaerially exposed part of the delta, while Agbada Formation is a regressive offlap succession that is formed under shallow-marine conditions in active depobelts of the delta (Reijers, 2011). The stratigraphy of the Niger Delta is classy by clastic wedge syndepositional collapse that occurred because of the results of marine shales being mobilized (Doust and Omatsola, 1990). Together with the expansion faults, change anticlines, sedimentary rock ridges, and sedimentary rock diapers exist within the basin and may be seen within the schematic structural profile of the Niger Delta (Tuttle et al., 1999). The ground of Niger Delta of African nation is formed of 3 geomorphological zones as well as the coastal or Lower Delta zone, Transition or Angiospermous tree zone and the fresh zone consists of dry flatlands and plains (Akpokodje, 1989; Teme, 2002). The Niger Delta region is characterized by tropical rain forest, with average annual rainfall from $2000 \mathrm{~mm}$ within the fresh zone to over $4000 \mathrm{~mm}$ at the coast that accounts for nearly $85 \%$ of the annual rainfall; the coastal and Angiospermous tree zones contain nearly $70 \%$ of marshes and swamps that occupy, which are sometimes submerged throughout the wet season (April to October). Figure 1 shows the Map of the Niger Delta region. 


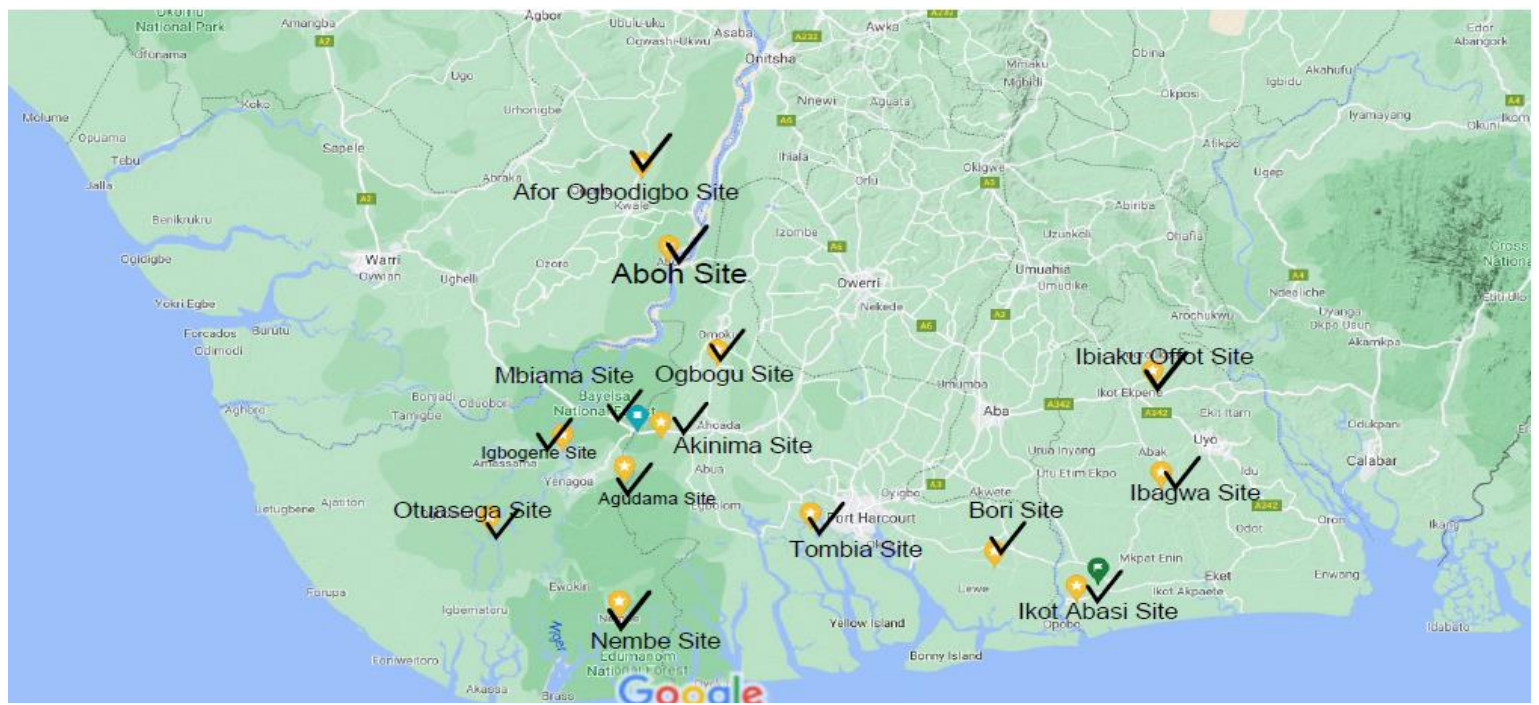

Figure 1: Study areas of Niger Delta

\subsection{Soil sample collection}

The soil samples for this study were collected from 4 states out of the 6 South-South states of the Niger Delta Region of Nigeria namely Rivers, delta, Akwa-Ibom and Bayelsa States. Five sites were located Rivers State (Akinima, Mbiama, Obite, Tombia and Bori Towns), Four sites in Bayelsa State (Igbogene, Agudama, Otuasega and Nembe Towns), Three sites in Akwa Ibom State (Ikot Abasi, Ikot, Ibagwa and Ibiaku Offot Towns) and Two sites in Delta State (Aboh and Afor Ogbodigbo Towns). The sites are tabulated in Table 1. The soil samples were collected from the subsurface at the sites by drilling and boring using the standard penetration test (SPT). Some analyses were performed right in the field (in-situ tests) and in the laboratory. The tests were conducted for estimation of dynamic soil properties. The soil samples were dried, crushed and sieved on sieve No $4(4.75 \mathrm{~mm})$.

Table 1: Test samples and their locations

\begin{tabular}{lll}
\hline State & Location & Sample \\
\hline Rivers & Akinima & SILT-A12 \\
& Mbiama & SILT-B18 \\
& Obite & SILT-C2 \\
& Tombia & SILT-D12 \\
& Bori & SILT-E5 \\
Bayelsa & Igbogene & SILT-F11 \\
& Agudama & SILT-G6 \\
& Otuasega & SILT-H17 \\
Akwa-Ibom & Nembe & SILT-I6 \\
& Ikot-Abasi & SILT-J14 \\
& Ibagwa & SILT-K13 \\
Delta & Ibiaku Offot & SILT-L5 \\
& Aboh & SILT-M6 \\
& Afor Ogbodigbo & SILT-N16 \\
\hline
\end{tabular}

Soil samples were remoulded to field density and natural moisture content stage. Samples were prepared with specimen standard measurements of $20 \mathrm{~mm}$ height and $70 \mathrm{~mm}$ diameter, placed in membrane of rubber, mounted on bottom plate of cyclic direct simple shear machine of confined rings of control lateral deformation at consolidation stages.

\subsection{Resonant column test}

Resonant Column Test is a laboratory test commonly applied in geotechnical engineering practice to determine the shear elastic modulus and damping properties of soils. The damping can be determined either from the frequency response function by evaluating the bandwidth of the resonance peak, or from the decay of the free vibration. The bottom end is often fixed and the top end is capable of exciting the specimen by torsional or longitudinal vibration and also of measuring the soil response. The test commences by vibrating the cylindrical soil specimen at the top end while the sample is restrained at the bottom. The frequency of vibration is increased gradually until reaching the fundamental frequency in the first-mode of vibration of the sample. At this frequency, measurements 
are made of the resonance frequency and amplitude of vibration. With the known geometry and end constraints of the sample, the measured resonance frequency is then used to calculate the wave propagation velocity using the wave propagation and directly from the derived velocity and the density of the sample. The RC equipment used is of a bottom-fixed and top-free configuration. It is equipped with associate magnetic driving head with accuracy wound coils and internally mounted, counter balanced accelerometers. It accommodates soil specimen up to $50 \mathrm{~mm}$ in diameter and $100 \mathrm{~mm}$ tall, with cell pressure capability of $1 \mathrm{MPa}$. The axial deformation of the specimen is measured by an interior high-resolution LVDT.

\subsection{Bender element test}

The bender Element (BE) technique is globally used methodology to acquire, generate and receive Pand $\mathrm{S}$-waves in soil specimens that propagate from one stop to the opposite. The Bender Element (BE) measures the peak (maximum) shear modulus $\left(G_{\max }\right)$ of a soil sample. This data is used to verify the stiffness of a soil. It is a key parameter in tiny/small strain dynamic analysis, like those to predict soil behaviour or soil structure interaction within and during earthquakes, explosion or machine and traffic induced vibrations. The bender element system contains piezoceramic transmitter. The receiver receives the electrical signal. The time period of the shear wave from the transmitter to the receiver is set exploitation proprietary software package that allows the operator to speedily calculate the shear wave speed. The bender element is used with tri-axial started for advanced applications. The bender element area unit typically fitted in an exceedingly normal resonant column (RC) equipment.

\subsection{Results and Discussion}

The effects of confinement pressure on frequency, shear modulus $G_{\max }$, shear velocity and damping ratio $D_{\min }$ of silt samples was studied in selected States of the Niger Delta region of Nigeria using the resonant column and bender elements $(\mathrm{RC} / \mathrm{BE})$ tests. The test samples in Table 1 were simultaneously compacted for the analysis.

\subsection{Frequency variation with confinement in the soils}

Figure 2 shows the profiles of frequency versus confinement pressure induced in silt layer across the respective sites in Rivers, Bayelsa, Akwa-Ibom and Delta States. The confined pressures ranged from 11 to $225 \mathrm{kPa}$. As pressure was increased, frequency response equally increased. Thus, at confinement of $11 \mathrm{kPa}$, frequency response ranged from sand $39.93-48.83 \mathrm{~Hz}$, while at the highest confinement of $225 \mathrm{kPa}$, it ranged from sand $59.10-66.14 \mathrm{~Hz}$.

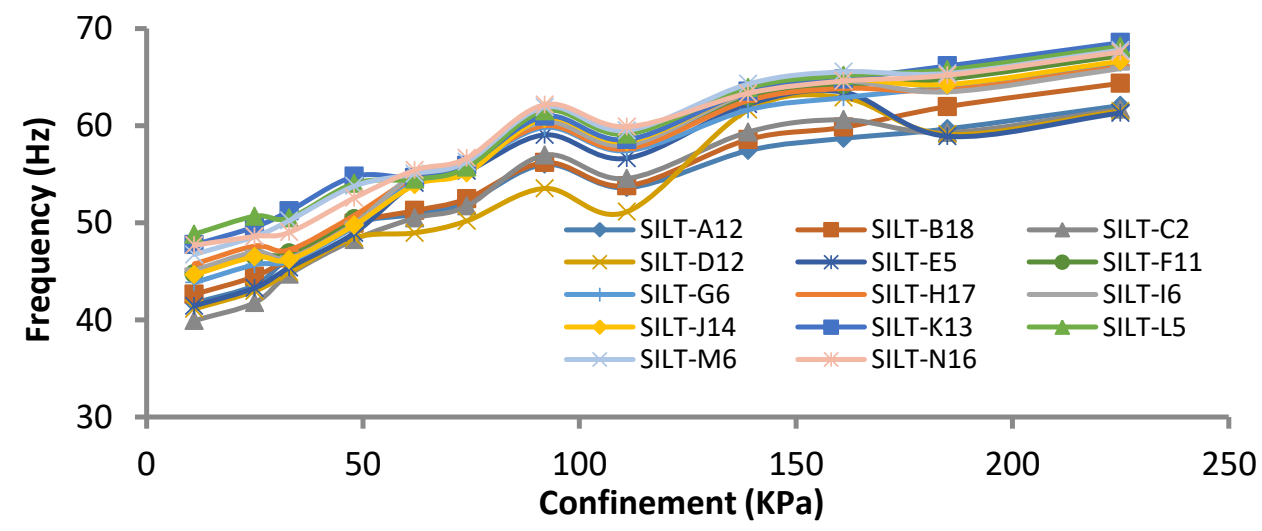

Figure 2: Variation of frequency with confinement

\subsection{Variation of parameters for resonance column analysis}

The shear modulus $\left(G_{m a x}\right)$, accelerometer output $\left(V_{r m s}\right)$ and damping ratio $\left(D_{\min }\right)$ results from Resonance Column (RC) test are shown below. Figures 3 to 5 show the $V_{r m s}, G_{\max }$ and $D_{\min }$ versus confinement pressure. From Figure 3, $V_{r m s}$ initially increases when the confinement increased from 11 $\mathrm{kPa}$ to $61 \mathrm{kPa}$ across all the sites, which then decreased slightly to $225 \mathrm{kPa}$ in all the sites. On the other hand, the $G_{\max }$ initially increased at pressure increase of 11 to $25 \mathrm{kPa}$, and the decreases as confinement pressure increased from 11 to $33 \mathrm{kPa}$ across all the sites. However, from pressure 
increase of $33 \mathrm{kPa}$ to $225 \mathrm{kPa}, G_{\max }$ increases slowly across all the sites. Also, the variation in minimum damping ratio $\left(D_{\min }\right)$ across the sites as confinement was increased can be described as a wavy like function, which increases at some pressures, and at other pressures, it then decreases.

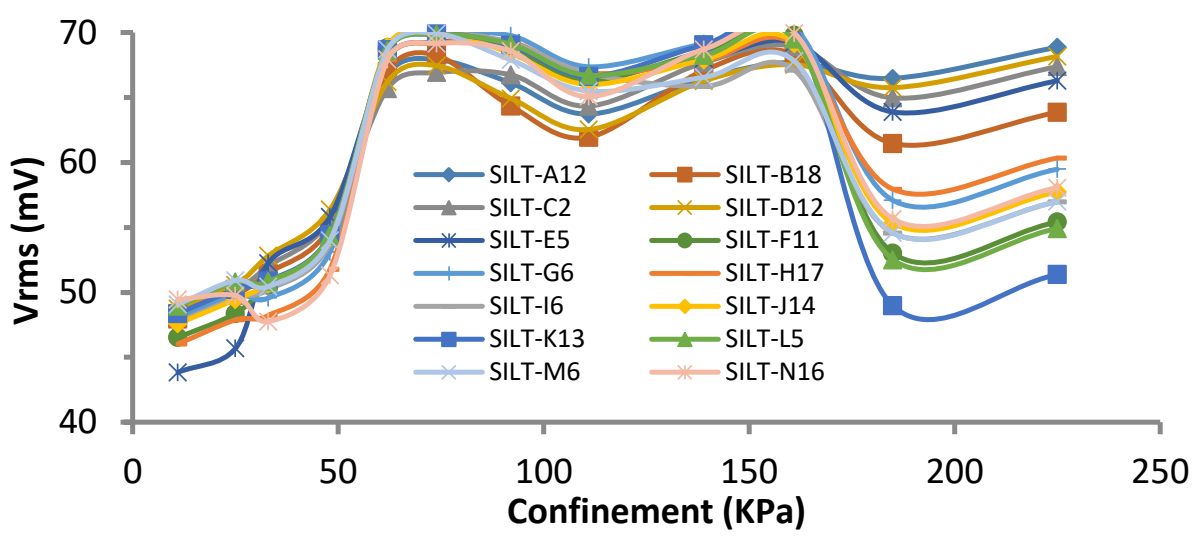

Figure 3: Variation of $V_{r m s}$ with confinement

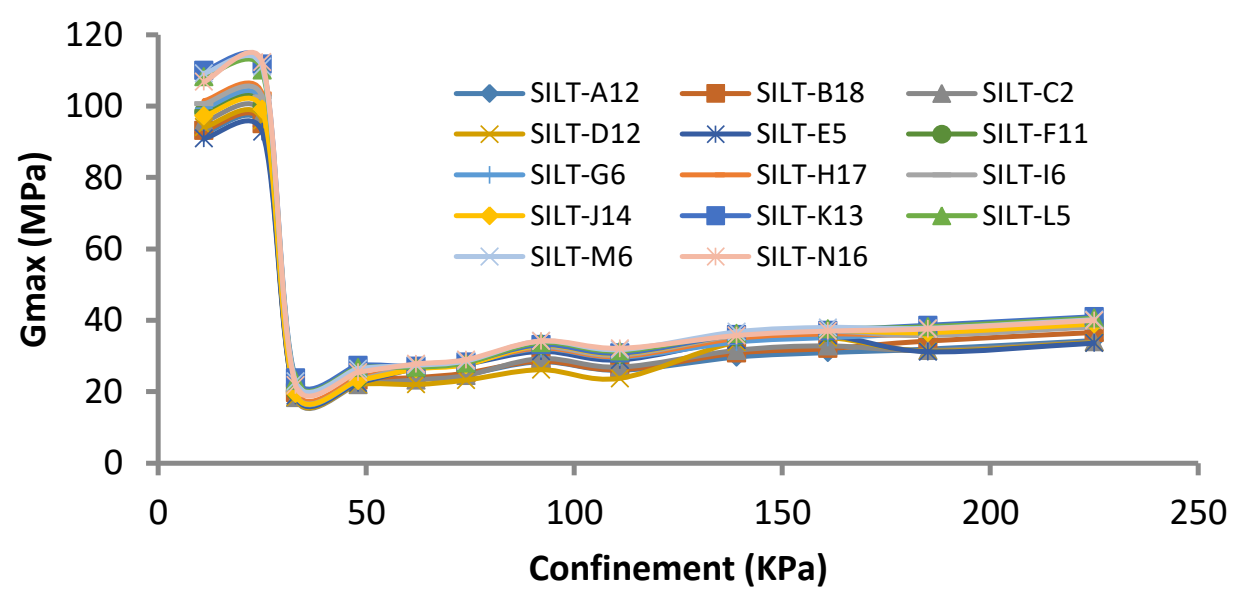

Figure 4: Variation of $G_{\max }$ with confinement

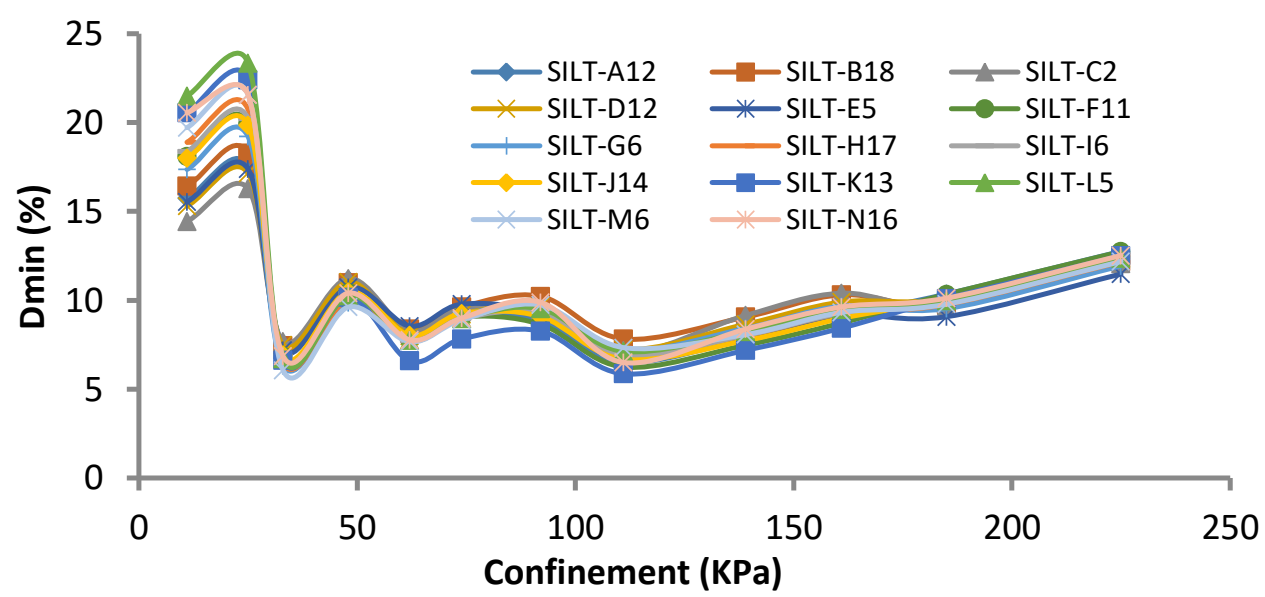

Figure 5: Variation of $D_{\min }$ with confinement

However, from confinement of $33 \mathrm{kPa}$ to $225 \mathrm{kPa}, D_{\text {min }}$ generally increase with confinement. This behaviour was said to be due to moisture content variation in soil strata (Thevanayagam, 1998; Anbazhagan et al., 2009; Tsai et al., 2009; Ige et al., 2016).

\subsection{Variation of parameters for bender element analysis}

Figures 6, 7 and 8 show the bender element (BE) tests for the shear wave-velocity $\left(V_{s}\right)$, shear modulus $\left(G_{\max }\right)$ and damping ratio $\left(D_{\min }\right)$ versus confinement, respectively. Thus, while $V_{s}$ and $G_{\max }$ generally increased as confinement pressure increases, the damping ratio $\left(D_{\min }\right)$ decreases with increase in 
confinement pressure. Though, there was initial increase in $D_{\min }$ as pressure was increased from 11 to $48 \mathrm{kPa}$ before decreasing again as confinement increased to $139 \mathrm{kPa}$.

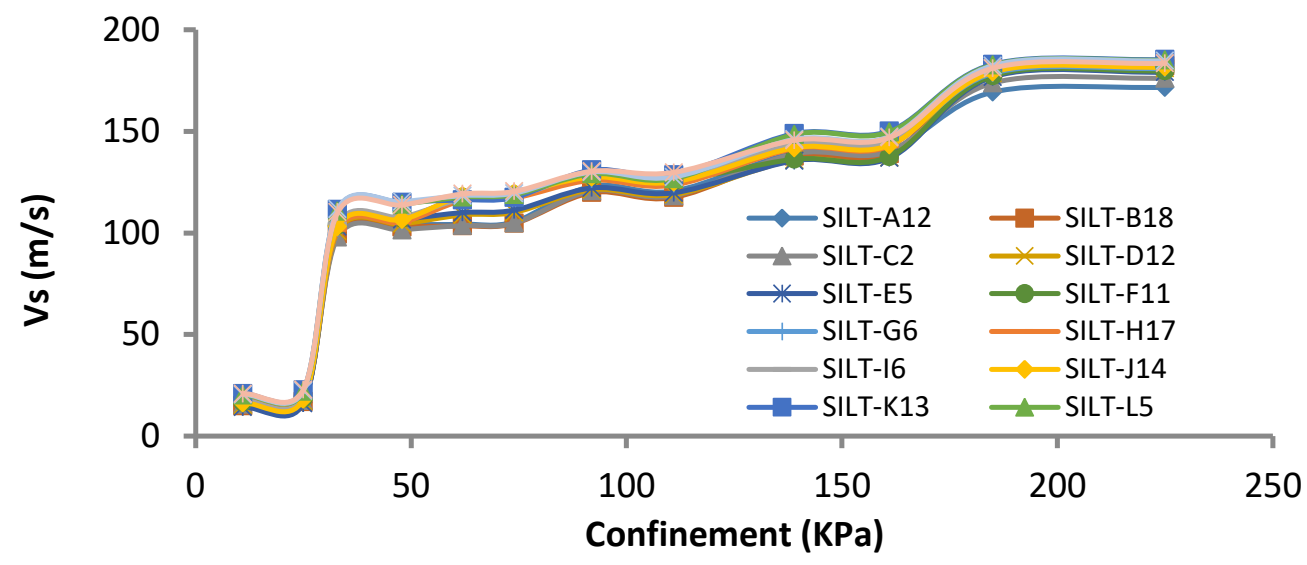

Figure 6: Variation of $V_{s}$ with confinement

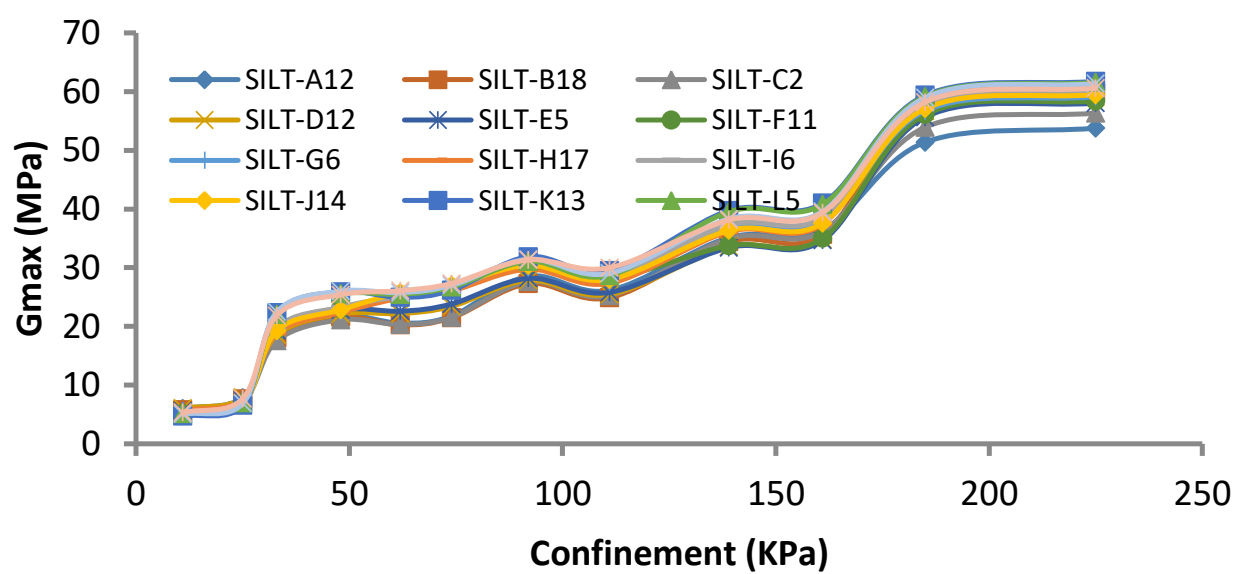

Figure 7: Variation of $G_{\max }$ with confinement

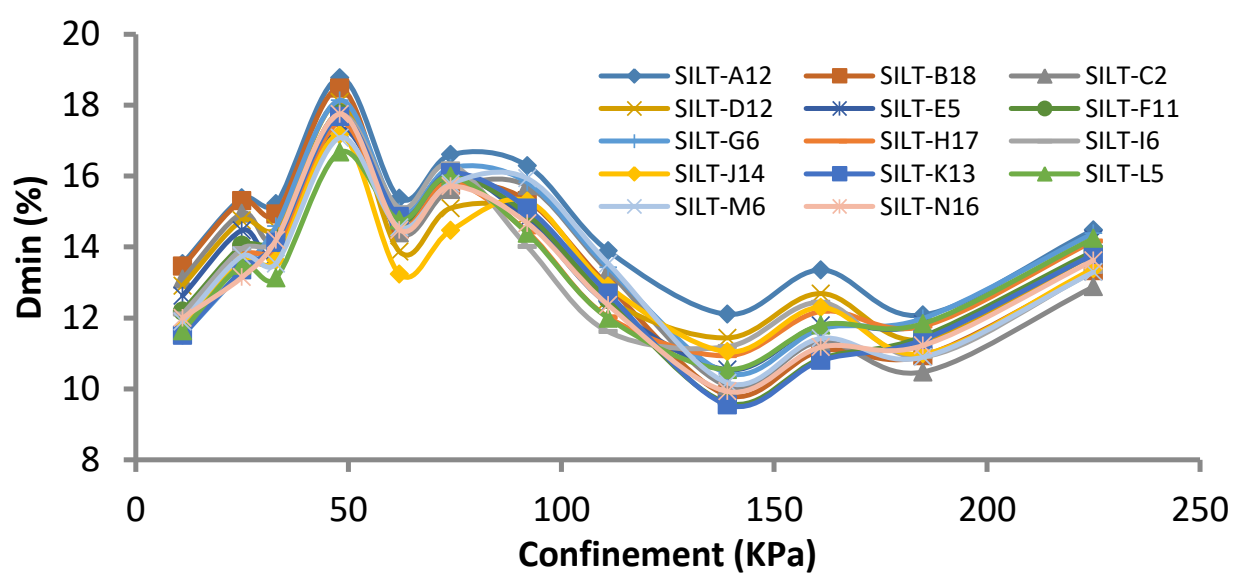

Figure 8: Variation of $D_{\min }$ with confinement

The minimum value of $V_{\text {rms }}$ recorded across the sites for the RC test ranged between $43.85 \mathrm{mV}$ and $49.45 \mathrm{mV}$, while the maximum value was between $68.16 \mathrm{mV}$ and $70.39 \mathrm{mV}$. Also, the shear wavevelocity $\left(V_{s}\right)$ measured from the BE test across the sites has minimum value between $14.32 \mathrm{~m} / \mathrm{s}$ and $20.94 \mathrm{~m} / \mathrm{s}$, while the maximum value was between $171.69 \mathrm{~m} / \mathrm{s}$ and $185.37 \mathrm{~m} / \mathrm{s}$ at confinement range of 11 to $225 \mathrm{kPa}$. It can be deduced that accelerometer decreases with confined pressure, while shear wave-velocity $\left(V_{s}\right)$ generally increase with confinement pressure. This observation agreed with the work of Asef and Najibi (2013) which also reported increase in shear wave velocity as confine pressure was increased. According to this study, initial increase in shear wave velocity represents a poroelastic regime, which becomes linear above the critical pressure. 
Similarly, the minimum value of $G_{\max }$ recorded across the sites ranged between $18.36 \mathrm{Mpa}$ and 23.79 Mpa with RC test and 4.70 Mpa and 6.03 Mpa with BE test, while the maximum value was between 92.82 Mpa and 112.33 Mpa with RC test and 53.77 Mpa and 61.75 Mpa with BE test. Finally, the minimum value of $D_{\min }$ recorded across the sites ranged between $5.87 \%$ and $7.44 \%$ with RC test and $9.55 \%$ and $12.10 \%$ with BE test, while the maximum value was between $16.28 \%$ and $23.34 \%$ with RC test and $16.68 \%$ and $18.77 \%$ with BE test. It was observed that the values of shear modulus and damping ratio obtained from the $\mathrm{RC}$ test were higher than those from the $\mathrm{BE}$ test at all confinement. Variations of results obtained via BE tests as compared to RC tests are reported by some authors (Chan and Jenu, 2014; Szilvágyi et al., 2016; Gluchowski et al., 2020).

Earlier study had reported a distinct behaviour of shear modulus of sand obtained from the BE and RC tests at varying particle size for confinement pressure of $0-400 \mathrm{kPa}$ (Souto and Ozudogru, 1994). Thus at 0-2 mm, there was no significant difference between the shear modulus obtained via the BE test from RC test, but at $0-8 \mathrm{~mm}$ the shear modulus for BE tests was higher than that of RC test, and higher than that of RC tests at 0-18 mm crushed till. The deviation of BE tests from the RC tests was attributed to shear strain amplitudes (Chan and Jenu, 2014), but with precise source and receiver signals, accurate sampling interval and frequency, improvement on consistency and compatibility of $\mathrm{BE}$ tests with RC test could be achieved , especially for multiple measurements (Szilvágyi et al., 2016). Analysis of $G_{\max }$ and $D_{\min }$ is vital for accurate interpretation of soil dynamics, calculation of ground movements and interaction between soil and structures, especially during foundation or when subjected to cyclic and dynamic loading (Kalioghlou et al., 2008).

\subsection{Conclusions}

Resonant column and bender element test performance analysis on compacted silt samples in Niger Delta States showed that confinement has influence on frequency response, shear modulus, shear velocity and damping ratio in silt soil. Thus, while some parameters increased with pressure increase, others decreased with increase in confinement pressure. The variations in the test parameters showed that the silty soil in the Niger Delta region is likely to experience earthquake in the future, especially as several geological activities are carried out in the region. Hence, adequate monitoring of the different soil strata in the region, through the evaluation of soil dynamic properties will help for accurate interpretation of soil dynamics, calculation of ground movements and interaction between soil and structures when subjected to cyclic and dynamic loading. This will also assist in proper understanding of the soil properties as influenced by load or oil exploration activities.

\section{References}

Akpokodje, E. G. (1989). Preliminary studies of the Niger Delta sub soils. Engineering Geology, 26, pp. $247-257$.

Amini, F. (1993). Effect of confining pressure on dynamic soil properties using improved transfer function estimators. Soil Dynamics and Earthquake Engineering, 12, pp. 145-147.

Anbazhagan, P., Sitharam, T. G. and Vipin, K. S. (2009). Site classification and estimation of surface level seismic hazard using geophysical data and probabilistic approach. Journal of Applied Geophysics, 68, pp. 219-230.

Asef, M. R. and Najibi, A. R. (2013). The effect of confining pressure on elastic wave velocities and dynamic to static Young's modulus ratio, Geophysics, 78(3), pp. 135-142.

Balendra, T. (2011). Demand and capacity analysis of buildings subjected to long distance earthquake. In: Procs. of International Conference on Earthquake analysis and design of structures department of civil engineering PSG college of technology, Coimbatore, India, pp. 24-29.

Borcherdt, R. D. (1994). Estimates of site-dependent response spectra for design (methodology and justification). Earthquake Spectra, 10(4), pp. 617-653. 
Chan, C. M. and Jenu, M. Z. M. (2014). Monitoring the stiffness change in clay with bender element and electromagnetic methods. In: Procs of 4th Int'l Conf. on GEOMATE, Australia, 19-21 ${ }^{\text {st }}$ November, 2014, pp. 179-185.

Cho, N. F., Tiampo, K. F., Mckinnon, S. D., Vallejos, J. A., Klein, W. and Dominguez, R. (2010). A simple metric to quantify seismicity clustering. Nonlinear Processes in Geophysics, 17, pp. 293-302.

Doust, H. and Omatsola, E. (1990). Niger Delta in divergent/passive margin basins, In: AAPG Memoir (Ed. by J.D. Edwards and P.A. Santogrossi), v. 48, p. 201-238.

Emoyan, O. O., Akpoborie, I. A. and Akporhonor, E. E. (2008). The Oil and Gas Industry and the Niger Delta: Implications for the Environment. J. Appl. Sci. Environ. Manage, 12(3), pp. 29 - 37.

Głuchowski, A., Skutnik, Z., Biliniak, M., Sas, W. and Lo Presti, D. (2020). Laboratory characterization of a compacted-unsaturated silty sand with special attention to dynamic behavior. Appl. Sci., 10, 2559. https//dx.doi:10.3390/app10072559.

Hills, P. B. and Penney, A. R. (2008). Management of seismicity at the Beaconsfield Gold Mine, Tasmania. In: Proceedings of $10^{\text {th }}$ underground operators' conference, Launceston, Tasmania, Australia: Australasian Institute of Mining and Metallurgy, pp. 157-170.

Hudyma, M. amd Potvin, Y. (2010). An engineering approach to seismic risk management in hardrock mines. Rock Mechanics and Rock Engineering, 43, pp. 891-906.

Ige, O. O., Oyeleke, T. A, Baiyegunhi, C. and Oloniniyi, T. L. (2016). Liquefaction, Landslide and Slope Stability Analyses of Soils: A Case Study of Soils from Part of Kwara, Kogi and Anambra States of Nigeria. Natural Hazards Earth System Science Discussions. Available at: http://www.doi:10.5194/nhess-2016-297, Accessed: July 24, 2018.

Kalioghlou, P., Tika, T. and Pitilakis, K. (2008). Shear modulus and damping ratio of cohesive soils. Journal of Earthquake Engineering, 12(6), pp.879-913.

Kgarume, T., Spottiswoode, S., and Durrheim, R. (2010). Statistical properties of mine tremor aftershocks. Pure and Applied Geophysics, 167, pp. 107-117.

Malek, F. and Leslie, I. S. (2006). Using seismic data for rockburst re-entry protocol at Inco's Copper Cliff North Mine. In: Procs. of $41^{\text {st }}$ U.S. symposium on rock mechanics. Golden, USA: American Rock Mechanics Association.

Mendecki, A. J. and Lynch, R. A. (2004). Gap601a: Experimental and theoretical investigation of fundamental processes in mining induced fracturing and rock instability close to excavations. Johannesburg: ISS International Limited.

Potvin, Y. (2009). Strategies and tactics to control seismic risks in mines. Journal of the South African Institute of Mining and Metallurgy, 109, pp. 177-186.

Reijers, T. J. A. (2011). Stratigraphy and sedimentology of the Niger Delta, Geologos, 17(3), pp. 133162.

Shima, E. (1978): Seismic Microzoning map of Tokyo. Proc. Second Inter. Conf. on Microzonation (1), pp. 433-443.

Souto, A., Hartikainen, J. and Ozudogru, K. (1994). Measurement of dynamic properties of road pavement materials by the bender element and resonant column tests. Geotechnique, 44(3), pp. 519526.

Szilvágyi, Z., Hudacsek, P. and Ray, R. P. (2016). Soil shear modulus from resonant column, torsional shear and bender element tests. Int. J. of GEOMATE, 10(2), pp. 1822-1827. 
Teme, S. C. (2002). Geotechnical considerations on foundations in the Niger Delta. Paper presented at Nigeria Mining and Geosciences Society, NMGS. Port Harcourt, Nigeria.

Thevanayagam, S. (1998). Effect of fines and confining stress on undrained shear strength of silty sands. Journal of Geotechnical and Geoenvironmental Engineering, 124(6), pp. 479-491.

Tsai, P. H., Lee, D. H., Kung, G. T. C. and Hsu, C. H. (2010). Effect of Content and Plasticity of Fines on Liquefaction Behaviour of Soils. Quarterly Journal of Engineering Geology and Hydrogeology, 43, pp. 95-106.

Tuttle, M. L. W., Charpentier R. R. and Brownfield, M. E. (1999). The Niger delta petroleum system: Niger delta province, Nigeria, Cameroon, and Equatorial Guinea, Africa: USGS Open file report 99$50-\mathrm{H}$.

UmaMaheshwari, R. Boominathan, A. and Dodagoudar, G. R. (2010). Use of surface waves in Statistical correlations of shear wave velocity and penetration resistance of Chennai soils. Geotech. Eng., 28, pp. 119-137.

Vallejos, J. A. and Mckinnon, S. D. (2010). Omori's law applied tomining-induced seismicity and reentry. Pure and Applied Geophysics, 167, pp. 91-106. 